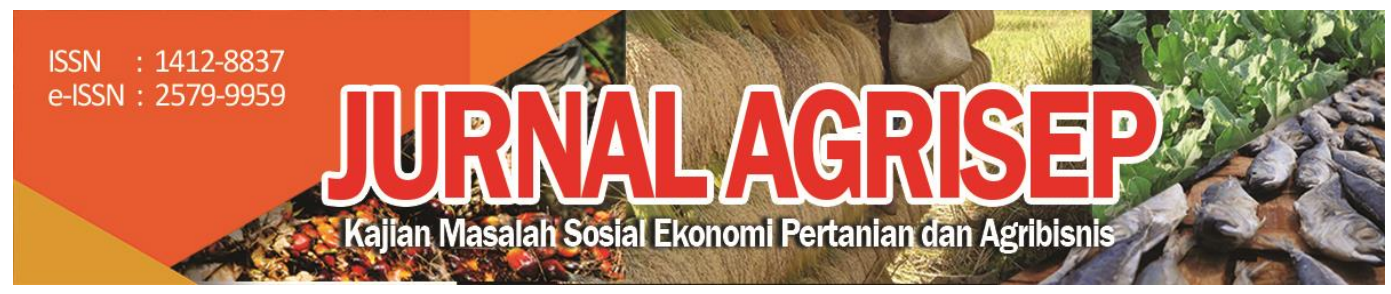

DOI: $10.31186 /$ jagrisep.19.2.255-274

\title{
STRATEGI PENINGKATAN KETAHANAN PANGAN DALAM MEMINIMALISASI STUNTING DI KABUPATEN SUKABUMI
}

\section{Strategy of Increasing Food Security in Minimizing Stunting in Sukabumi District}

\author{
Hadi Riajaya ${ }^{1}$; Adis Imam Munandar ${ }^{2)}$ \\ 1)Pascasarjana S2 Sekolah Kajian Stratejik dan Global, Universitas Indonesia \\ 2) Pengajar di Sekolah Kajian Stratejik dan Global, Universitas Indonesia \\ Email: dippodjaya@gmail.com
}

\begin{abstract}
Food security has becoming strategic issue in Sukabumi District in view of this district still having stunting prevalence $37 \%$. In other word, one of three children in Sukabumi District having stunting. This research aims to maping the level of society food resilience and to formulating the strategy of increasing food security in minimizing case of stunting in Sukabumi District. The method applied in this reasearch is descriptive qualitative which combined with EFE (External Factor Evaluation) and IFE (Internal Factor Evaluation) analysis in one formula SWOT (Strength Weakness Opportunity Threat). Research also used an approach of Global Food Security Index; and Food Security and Vulnerability Atlas. The results of this research are considered from affordability dimension, whole society could afford it; availability dimension, amount of food availability has fulfill the ideal standard; while quality and safety dimensions heve not fulfill the ideal standard. Sukabumi District are having 168 villages that food insecurity. The appropriate strategy of increasing food security in minimizing stunting is Diversification Strategy, which implementing through: (1) food diversification; (2) optimilizing food and livestock availability; (3) providing employment in agriculture areas; and (4) restraining the conversion of agricultural land.
\end{abstract}

Keywords: Food Security, Strategy, Stunting, Sukabumi District. 


\begin{abstract}
ABSTRAK
Ketahanan pangan menjadi isu strategis di Kabupaten Sukabumi mengingat kabupaten ini masih memiliki angka prevalensi stunting sebesar $37 \%$ atau dengan kata lain 1 dari 3 anak di Kabupaten Sukabumi mengalami stunting. Penelitian ini bertujuan untuk memetakan tingkat ketahanan pangan masyarakat dan merumuskan strategi peningkatan ketahanan pangan dalam meminimalisasi kejadian stunting di Kabupaten Sukabumi. Metode penelitian menggunakan deskriptif kualitatif dengan analisis data EFE (External Factor Evaluation) dan IFE (Internal Factor Evaluation) yang dirumuskan dalam satu analisis SWOT (Strength Weakness Opportunity Threat). Pendekatan penelitian menggunakan Global Food Security Index dan Food Security and Vulnerability Atlas. Hasilnya ditemukan bahwa ketahanan pangan ditinjau dari dimensi affordability dapat dijangkau oleh seluruh lapisan masyarakat, dimensi availability jumlah ketersediaan pangan telah memenuhi standar ideal, sementara dimensi quality and safety belum memenuhi standar ideal. Kabupaten Sukabumi memiliki jumlah desa rawan pangan sebesar 168 desa. Strategi peningkatan ketahanan pangan dalam meminimalisasi stunting yang paling tepat digunakan adalah Strategi Diversifikasi yang dilakukan melalui: (1) diversifikasi pangan; (2) optimalisasi ketersediaan pangan dan ternak; (3) penyediaan lapangan kerja pada industri pertanian; dan (4) membatasi konversi lahan pertanian.
\end{abstract}

Kata kunci: Ketahanan Pangan, Sukabumi, Strategi, Stunting.

\title{
PENDAHULUAN
}

Pangan merupakan kebutuhan dasar manusia yang paling utama dan pemenuhannya merupakan bagian dari hak asasi manusia yang dijamin di dalam Undang-Undang Dasar 1945 sebagai komponen dasar untuk mewujudkan sumber daya manusia yang berkualitas (Undang-Undang 18 tahun 2012). Pangan senantiasa harus terjamin dengan cukup oleh pemerintah dan terjangkau oleh daya beli masyarakat dalam memenuhi kebutuhan seharihari sebagai cerminan kemakmuran dan kesejahteraan rakyat Indonesia. Kecukupan pangan berperan penting dalam menentukan kualitas intelegensi sumber daya manusia (Elizabeth, 2011).

Undang-Undang Nomor 18 Tahun 2012 tentang Pangan menjelaskan bahwa Ketahanan Pangan sebagai suatu kondisi terpenuhinya pangan bagi suatu negara sampai dengan perseorangan, yang tercermin dari tersedianya pangan yang cukup, baik jumlah maupun mutunya, aman, beragam, bergizi, merata, dan terjangkau serta tidak bertentangan dengan agama, keyakinan, dan budaya masyarakat, untuk dapat hidup sehat, aktif, dan produktif secara berkelanjutan. Ketahanan pangan juga dirumuskan sebagai adanya keterjaminan seluruh masyarakat di dalam suatu kawasan/wilayah tercukupi kebutuhan pangannya dan gizinya yang merupakan syarat utama untuk mencapai derajat kesehatan dan kesejahteraan, yang dapat diukur melalui 
kecukupan/ketersediaan, stabilitas ketersediaan, dan aksesibilitas (Ketaren, 2015).

Ketahanan pangan merupakan komponen yang tidak dapat dipisahkan dari ketahanan nasional. Hal ini dikarenakan ketahanan pangan memiliki sinergi terhadap sektor perekonomian suatu bangsa yang erat kaitannya dengan pengambilan kebijakan negara tersebut. Sementara puncak ketahanan pangan adalah pencapain status nutrisi, dimana salah satunya adalah ketahanan untuk pemenuhan gizi dalam mencegah dan menangani stunting. Kesinambungan secara berurut bahwa stunting merupakan bagian dari terpenuhinya nutrisi yang merupakan gambaran dari ketahanan pangan, selanjutnya ketahanan pangan menentukan kualitas sumber daya manusia dan stabilitas ekonomi sosial politik sebagai prasyarat untuk melaksanakan pembangunan. Pada akhirnya ketahanan pangan yang kuat akan menciptakan suatu ketahanan nasional yang kuat pula.

Ketahanan pangan sebagaimana dijelaskan di atas perlu mendapat perlakuan khusus untuk terus ditingkatkan, karena pada akhirnya akan berkaitan dengan status gizi dan kesehatan. Pada skala nasional Indonesia, permasalahan kesehatan masih menghadapi berbagai persoalan. Salah satu diantaranya adalah masih ditemukannya kejadian gizi buruk dan gizi kurang diberbagai wilayah nusantara, terutama terjadi pada anak balita (bawah lima tahun). Hal ini berdasarkan hasil Pemantauan Status Gizi 2017 yang dilakukan oleh Kementerian Kesehatan. Selanjutnya batasan untuk kategori status gizi balita dibagi menjadi tiga jenis, yaitu: underweight/berat badan kurang, stunting/pendek, dan wasting/kurus. Adapun program yang saat ini gencar disosialisasikan oleh pemerintah adalah pencegahan dan penanganan stunting.

Stunting adalah gambaran kondisi gagal tumbuh pada anak usia dibawah lima tahun dikarenakan kekurangan gizi kronis, sehingga anak tumbuh tidak maksimal yang terlihat dari postur tubuh yang rendah dibandingkan anak seusianya. Kekurangan gizi kronis terjadi pada trimester pertama kehamilan sampai bayi dilahirkan, namun stunting akan terindentifikasi pada saat anak menginjak umur dua tahun, sehingga untuk mengantisipasi kejadian tersebut, maka periode 1000 hari pertama kehidupan seorang anak terhitung sejak awal masa kehamilan semestinya sudah dipenuhi segala bentuk kebutuhan.

WHO-MGRS (Multicentre Growth Reference Study) pada tahun 2006 memberikan standar baku bahwa balita dikategorikan pendek (stunted) dan sangat pendek (severely stunted) adalah balita dengan panjang badan (PB/U) atau tinggi badan (TB/U) menurut umurnya. Kementerian Kesehatan RI mendefinisikan stunting kepada anak balita dengan nilai z-scorenya -2SD (kurang dari 2 standar deviasi) dikategorikan stunted dan -3SD (kurang dari 3 standar deviasi) dikategorikan severely stunted. Nilai z-score atau ambang batas dihitung berdasarkan Keputusan Menteri Kesehatan Nomor 1995/MENKES/SK/XII/2010 tentang Standar Antropometri Penilaian Status Gizi Anak. 
Direktorat Jenderal Kesehatan Masyarakat Kementerian Kesehatan (2017), secara terperinci menjelaskan bahwa dampak negatif dari stunting dapat mengakibatkan seseorang menjadi mudah sakit, kemampuan kognitif berkurang, saat tua beresiko terkena penyakit berhubungan dengan pola makan, fungsi-fungsi tubuh tidak seimbang, mengakibatkan kerugian ekonomi, dan postur tubuh yang tidak maksimal saat dewasa. Berdasarkan data WHO tahun 2017 yang dikutip oleh Tim Nasional Percepatan Penanggulangan Kemiskinan (TNP2K) yang dipaparkan pada Agustus 2018 dalam acara Gerakan Nasional Pencegahan Stunting dan Kerjasama Kemitraan Multi Sektor, disebutkan bahwa Indonesia saat ini merupakan negara dengan peringkat stunting nomor empat di dunia, dengan prevalensi penderita mencapai 8,8 juta anak yang tersebar di seluruh wilayah dan lintas kelompok pendapatan (TNP2K, 2018).

Stunting merupakan kondisi yang harus segera ditangani mengingat jumlah penderitanya yang tersebar secara menyeluruh diberbagai provinsi mencapai angka sebesar $37,2 \%$ dari seluruh populasi balita, atau dengan kata lain lebih dari 1 dari 3 anak Indonesia mengalami stunting (Kemenkes, 2017). Penderita paling banyak tersebar di Pulau Jawa dengan jumlah keseluruhan mencapai 4.353.000 anak. Lebih lanjut untuk penyebaran tersebut, Provinsi Jawa Barat teridentifikasi prevalensi penderita stunting tertinggi yang tersebar di 13 (tiga belas) kabupaten/kota dengan jumlah 1.048.348 anak (TNP2K, 2017). Prevalensi stunting paling besar ada di 3 (tiga) kabupaten yaitu: Sukabumi $(37,6 \%)$, Bandung $(38,7)$, dan Garut $(43,1 \%)$.

Selanjutnya berdasarkan luas wilayah se-provinsi Jawa Barat, maka Sukabumi berada pada urutan pertama yaitu memiliki luas sebesar 4.145,70 $\mathrm{km}^{2}$. Menjadi wilayah yang paling luas diantara ketiga kabupaten tersebut di atas sebanding dengan produksi padi yang terbesar pula, dapat dilihat pada tabel 1.

Tabel 1. Luas Wilayah, Jumlah Penduduk, dan Produksi Beras di Provinsi Jawa Barat Tahun 2017

\begin{tabular}{clccr}
\hline No & Kabupaten & $\begin{array}{c}\text { Luas Wilayah } \\
\left(\mathrm{km}^{2}\right)\end{array}$ & $\begin{array}{c}\text { Jumlah Penduduk } \\
\text { (jiwa) }\end{array}$ & $\begin{array}{c}\text { Produksi Beras } \\
\text { (Ton) }\end{array}$ \\
\hline 1 & Sukabumi & $4.145,70$ & 2.453 .498 & $1.027 .455,31$ \\
\hline 2 & Bandung & $1.767,96$ & 3.657 .601 & $546.414,64$ \\
\hline 3 & Garut & $3.074,07$ & 2.588 .839 & $942.843,72$ \\
\hline
\end{tabular}

Sumber: telah diolah kembali dari BPS Jabar, 2018

Gambaran kondisi terkait ketahanan pangan, Sukabumi telah mampu mencukupi kebutuhan logistik pangan terutama beras. Kabupaten Sukabumi tercatat memiliki cadangan pangan surplus produksi beras. Surplus beras pada daerah tersebut setiap tahunnya berkisar antara 250 ribu ton hingga 350 ribu 
ton, hal ini tergantung pada kondisi lama tidaknya musim penghujan (Hamami, 2019). Kondisi ini ternyata tidak menjamin ketahanan pangan setiap masyarakatnya, bahkan bertolak belakang dengan persentase angka anak penderita stunting yang masih relatif tinggi di Kabupaten Sukabumi.

Fokus pada daerah Kabupaten Sukabumi Provinsi Jawa Barat, menjelaskan bahwa penyandang stunting di Kabupaten Sukabumi sebesar $37,6 \%$. Ditinjau dari banyaknya balita yang mengalami stunting, meskipun dapat dikatakan bahwa Kabupaten Sukabumi surplus pangan terutama beras namun disisi lain pada kenyataannya tengah menghadapi permasalahan ketahanan pangan itu sendiri sekaligus juga ketahanan gizi yang mengakibatkan tingginya angka prevalensi penderita stunting. Selanjutnya Ketahanan Pangan dan Gizi merupakan satu kesatuan konsep dalam pembangunan manusia Indonesia yang berkualitas. Pembangunan pangan harus seiring dengan upaya pemenuhan konsumsi gizi masyarakat mengacu pada prinsip beragam, bergizi, seimbang, dan aman atau dikenal dengan istilah B2SA (Dewan Ketahanan Pangan, 2015).

Ketahanan pangan Kabupaten Sukabumi dalam hal ini perlu diperhatikan sesuai dengan indikator Global Food Security Index yang terdiri dari variabel affordability, availability, dan quality and safety, untuk mendeskripsikan sejauh mana ketahanan pangan Kabupaten Sukabumi. Selanjutnya ketahanan pangan juga diproyeksikan berdasarkan Peta Ketahanan dan Kerentanan Pangan atau Food Security and Vulnerability Atlas (FSVA) yang dikembangkan Badan Ketahanan Pangan Kementerian Pertanian, guna mendapatkan gambaran faktual.

Hasil ketahanan pangan Kabupaten Sukabumi selanjutnya akan dikomparasikan dengan ketahanan pangan secara nasional, guna melihat dan memetakan letak kekuatan dan kelemahan pangan diwilayah tersebut secara holistik. Selain itu, perlu penelitian yang lebih mendalam terkait prevalensi stunting pada umumnya terjadi diwilayah yang kekurangan sumber daya alam dan sumber daya manusia, sedangkan kejadian stunting di Kabupaten Sukabumi, merupakan daerah yang memiliki kualitas masyarakat dan hasil kekayaan alam yang memadai terutama pada produksi pangan beras (availability) yang tercatat berlebih (surplus).

Berdasarkan uraian permasalahan ketahanan pangan dan kejadian stunting yang dihadapi Kabupaten Sukabumi, maka tujuan dalam penelitian ini adalah menganalisis pemetaan ketahanan pangan di Kabupaten Sukabumi berdasarkan GFSI (Global Food Security Index) dan FSVA (Food Security and Vulnerability Atlas). Selanjutnya menganalisis dan merumuskan strategi peningkatan ketahanan pangan Kabupaten Sukabumi dalam meminimalisasi stunting. 


\section{Tinjauan Teoritis}

\section{Konsep Pangan}

Konsep pangan yang dianut Indonesia mendefinisikan pangan adalah segala sesuatu yang berasal dari sumber hayati, baik yang diolah maupun tidak diolah yang diperuntukkan sebagai makanan atau minuman bagi konsumsi manusia (Undang-Undang nomor 18 tahun 2012). Konsumsi pangan adalah jenis dan jumlah pangan yang dikonsumsi oleh seseorang dalam jangka waktu tertentu untuk hidup sehat dan produktif, perlu diatur melalui volume konsumsi pangan, konsumsi energi, dan konsumsi protein. Indikator dalam menilai kualitas konsumsi pangan adalah Pola Pangan Harapan (PPH). PPH merupakan susunan beragam pangan yang didasarkan atas proporsi keseimbangan energi berbagai kelompok pangan untuk memenuhi kebutuhan gizi (Badan Ketahanan Pangan, 2018).

\section{Konsep Ketahanan Pangan}

Pada dasarnya terdapat empat pilar yang menopang ketahanan pangan; pertama, aspek ketersediaan pangan (food availability); kedua, aspek stabilitas ketersediaan/pasokan (stability of supplies); ketiga, akses keterjangkauan (access to supplies); keempat, aspek konsumsi (food utilization). Ketahanan pangan nasional secara struktur dalam bangunan keempat pilar ketahanan pangan tersebut satu sama lainnya saling terkait (Khudori, 2009). Selanjutnya Safa'at (2013) merumuskan ketahanan pangan mencakup tiga unsur utama, yaitu: ketersediaan pangan; aksesibilitas (keterjangkuan); dan pemanfaatan. Ketahanan pangan juga ditekankan harus bertujuan untuk mewujudkan ketersediaan pangan bagi seluruh rumah tangga, dalam jumlah yang cukup, mutu dan gizi yang layak, aman dikonsumsi, merata, serta terjangkau oleh setiap individu (Susilo, 2017).

GFSI (2018) atau Global Food Security Index secara komprehensif menetapkan indeks ketahanan pangan lingkup internasional berdasarkan tiga dimensi yaitu: affordability (keterjangkauan), availability (ketersediaan), dan quality and safety (kualitas dan keamanan). Indeks ini adalah yang pertama untuk menguji ketahanan pangan berdasarkan ketiga dimensi tersebut, selain itu juga mencakup faktor penyesuaian pada sumber daya alam dan ketahanan. Kategori ini menilai paparan suatu negara terhadap dampak perubahan iklim; kerentanannya terhadap risiko sumber daya alam; dan bagaimana negara beradaptasi terhadap risiko-risiko tersebut. 


\section{Konsep Ketahanan Pangan dan Gizi}

Ketahanan pangan dan gizi adalah kondisi terpenuhinya kebutuhan pangan dan gizi bagi negara sampai dengan perseorangan, yang tercermin dari tersedianya pangan yang cukup, baik jumlah maupun mutunya, aman, beragam, memenuhi kecukupan gizi, merata dan terjangkau serta tidak bertentangan dengan agama, keyakinan, dan budaya masyarakat, untuk mewujudkan Status gizi yang baik agar dapat hidup sehat, aktif, dan produktif secara berkelanjutan (Peraturan Pemerintah RI Nomor 17 tahun 2015).

Ketahanan pangan dan perbaikan gizi merupakan suatu kesatuan, jika membahas mengenai ketahanan pangan, juga harus membicarakan perbaikan gizi, begitu pula sebaliknya. Keadaan gizi masyarakat adalah indikator utama ketahanan pangan, sedangkan kemandirian dan kearifan lokal merupakan perwujudan semangat menuju kedaulatan pangan (Kementerian Kesehatan, 2012).

\section{Konsep Manajemen Strategi}

Manajemen strategi adalah serangkaian keputusan-keputusan dan tindakan- tindakan manajerial yang mengarah kepada penyusunan strategi-strategi efektif untuk mencapai tujuan perusahaan dengan analisa S.W.O.T. (Wheelen, 2008).

\section{Konsep Stunting}

Stunting menggambarkan kegagalan pertumbuhan yang terjadi dalam jangka waktu yang lama, dan dihubungkan dengan penurunan kapasitas fisik dan psikis, penurunan pertumbuhan fisik, dan pencapaian bidang pendidikan rendah (UNICEF, 2004). Selanjutnya The Mother and Child Health and Education Trust (2009) menyatakan bahwa sunting adalah keadaan dimana tinggi badan berdasarkan umur rendah, atau keadaan dimana tubuh anak lebih pendek dibandingkan dengan anak-anak lain yang seusianya. Stunting menggambarkan status gizi kurang yang bersifat kronik pada masa pertumbuhan dan perkembangan sejak awal kehidupan. Stunting adalah kekurangan nutrisi jangka panjang dan seringkali mengakibatkan perkembangan mental yang tertunda, performa disekolah yang buruk dan berkurangnya kapasitas intelektual. Keadaan ini dipresentasikan dengan nilai z-score tinggi badan menurut umur (TB/U) kurang dari -2 standar deviasi (SD) berdasarkan standar pertumbuhan (WHO, 2010). 


\section{METODE PENELITIAN}

Penelitian ini menggunakan metode penelitian kualitatif dengan pendekatan deskriptif deduktif. Penelitian kualitatif merupakan metodemetode untuk mengeksplorasi dan memahami makna pada kondisi obyek alamiah yang menekankan pencarian makna, pengertian, konsep, karakteristik, gejala, simbol, maupun deskripsi tentang suatu fenomena. Tujuannya adalah untuk mengetahui dan memperoleh deskripsi mengenai strategi pemerintah daerah Kabupaten Sukabumi dalam menunjang ketahanan pangan dalam rangka meminimalisasi fenomena stunting yang terjadi diwilayah tersebut.

Pendekekatan penelitian dilakukan berdasarkan standar pengukuran ketahanan pangan Global Food Security Index yang terdiri dari variabel affordability, availability, dan quality and safety untuk melakukan pendataan dan pemetaan daerah yang masuk kategori tahan pangan dan rawan pangan, terutama daerah yang diindikasikan tingginya angka prevalensi stunting. Selanjutnya pemetaan ketahanan pangan diproyeksikan menggunakan pendekatan Food Security and Vulnerability Atlas atau peta ketahanan dan kerentanan pangan dengan tujuh indikator penilaian.

Teknik pengumpulan data melalui penelitian lapangan (field rescarch) dan studi kepustakaan (library studies). Data dalam penelitian bersumber pada data primer dan data sekunder. Data primer diperoleh pada saat penelitian langsung dilapangan dengan cara observasi lapangan dan wawancara langsung dengan ahli (expert) yang berkompeten. Pada penelitian ini yang akan menjadi ahli (expert) adalah: Kepala Dinas Ketahanan Pangan Kabupaten Sukabumi; Kepala Dinas Pertanian Kabupaten Sukabumi; Kepala Dinas Kesehatan Kabupaten Sukabumi; Kepala Bidang Ketersediaan; Kepala Bidang Distribusi; Kepala Bidang Konsumsi; dan Kepala Bidang Kesehatan Masyarakat.

Data sekunder yang dipergunakan dalam hal ini berupa Undang-Undang Nomor 18 Tahun 2012 tentang Pangan, serta peraturan perundang-undangan lain di tingkat pusat maupun daerah yang terkait dengan pokok permasalahan penelitian, data BPS yang berupa Kabupaten Sukabumi dalam angka, Dinas Ketahanan Pangan Kabupaten Sukabumi, Buku Saku Pemantauan Status Gizi Kementerian Kesehatan, Tim Nasional Percepatan Penanggulangan Kemiskinan, buku-buku, hasil-hasil penelitian, jurnal-jurnal, artikel-artikel koran, dokumen tertulis program ketahanan pangan dan data dari instansi terkait lainnya.

Teknik analisa data menggunakan teknik External Factor Evaluation (EFE) atau Evaluasi Faktor Eksternal adalah alat yang baik untuk memvisualisasikan dan memprioritaskan faktor peluang dan ancaman eksternal yang dihadapi. Selanjutnya teknik Internal Factor Evaluation (IFE) atau Evaluasi Faktor Internal digunakan untuk mengetahui faktor-faktor internal pemerintah berkaitan dengan kekuatan dan kelemahan yang dianggap penting. Hasil dari analisa 
internal akan diperoleh profil kekuatan (strength) dan kelemahan (weakness), sedangkan dari analisa lingkungan eksternal akan diperoleh profil peluang (opportunity) dan ancaman (threat). Pada akhirnya analisa kedua lingkungan tersebut akan dirumuskan dengan analisa SWOT untuk mengidentifikasi berbagai faktor secara sistematis untuk merumuskan strategi pemisahaan didasarkan pada logika yang dapat memaksimalkan kekuatan dan peluang, namun secara bersamaan dapat meminimalkan kelemahan dan ancaman.

\section{HASIL DAN PEMBAHASAN}

\section{Hasil Penelitian}

Ketahanan pangan suatu wilayah dipengaruhi oleh sumber daya alam dan sumber daya manusia, disamping itu peran penting pemerintah selaku pemangku kebijakan juga berpengaruh dalam pengaturan sistem politik, struktur ekonomi, sosial budaya dan lingkungan, oleh karenanya perlu dibangun suatu sistem yang secara berkelanjutan dalam meningkatkan ketahanan pangan suatu wilayah. Pada penelitian ini, pemetaan ketahanan pangan dideskripsikan menggunakan Global Food Security Index (GFSI) yang menetapkan indeks ketahanan pangan berdasarkan tiga dimensi sebagai berikut:

\section{Dimensi Affordability}

Affordability atau keterjangkauan pangan Kabupaten Sukabumi diukur berdasarkan menggunakan 6 indikator, yaitu: konsumsi makanan sebagai bagian dari pengeluaran rumah tangga; proporsi populasi di bawah garis kemiskinan global; produk domestik bruto per kapita; impor pertanian; adanya program pengamanan pangan; dan akses pembiayaan untuk petani. Berdasarkan enam indikator dimensi affordability yang telah diuraikan di atas, secara garis besar dapat digambarkan bahwa affordability pangan di Kabupaten Sukabumi dapat dijangkau seluruh lapisan masyarakat. Hanya saja masih ada beberapa wilayah di Kabupaten Sukabumi yang akses pangannya sulit dijangkau, diantaranya disebabkan oleh akses jalan, jumlah sarana kesehatan, jumlah warung dan kemiskinan.

Kondisi daya beli masyarakat Kabupaten Sukabumi secara keseluruhan adalah memadai berdasarkan persentase pengeluaran pangan di rumah tangga dengan nilai 58,4\% (Dinas Ketahanan Pangan, 2018). Berdasarkan indikator affordability, maka perbandingan kondisi tingkat affordability atau keterjangkauan pangan Kabupaten Sukabumi secara umum setara atau sama dengan tingkat affordability nasional, artinya pangan dapat dijangkau dengan baik oleh seluruh lapisan masyarakat Kabupaten Sukabumi dalam pemenuhan gizi dan status ketahanan pangan. 


\section{Dimensi Availability}

Availability atau ketersediaan pangan Kabupaten Sukabumi diukur berdasarkan 8 indikator dengan 5 sub indikator, yaitu: kecukupan pasokan (pasokan makanan rata-rata, ketergantungan pada bantuan makanan); pengeluaran publik untuk penelitian dan pengembangan pertanian; infrastruktur pertanian (keberadaan fasilitas penyimpanan pangan yang memadai, infrastruktur jalan, infrastruktur pelabuhan); volatilitas produksi pertanian; risiko stabilitas politik; korupsi; kapasitas penyerapan; dan kehilangan makanan. Situasi ketersediaan pangan di Kabupaten Sukabumi dijelaskan bahwa ketersediaan pangan telah tercukupi. Hal ini dapat dilihat melalui ketersediaan energi sebesar 2,398 kkal/kap/hari dan ketersediaan protein sebesar $88 \mathrm{~g} / \mathrm{kap} / \mathrm{hari}$. Menurut kuantitas ketersediaan pangan di Kabupaten Sukabumi telah memenuhi kebutuhan.

Berdasarkan poin-poin yang telah dijabarkan di atas, maka perbandingan kondisi tingkat availability atau ketersediaan pangan Kabupaten Sukabumi secara umum satu tingkat lebih baik daripada availability nasional. Artinya ketersediaan pangan untuk lingkungan masyarakat Kabupaten Sukabumi dalam kategori cukup dan memadai.

\section{Dimensi Quality and Safety}

Quality and Safety atau kualitas dan keamanan pangan Kabupaten Sukabumi diukur berdasarkan menggunakan 5 indikator dengan 9 sub indikator, yaitu: diversifikasi makanan; standar nutrisi (pedoman gizi nasional, rencana atau strategi gizi nasional, pemantauan dan pengawasan gizi); ketersediaan mikronutrien (ketersediaan vitamin a dalam makanan, ketersediaan makanan dari sumber hewani, ketersediaan makanan dari sumber nabati); kualitas protein; dan keamanan pangan (badan/lembaga untuk memastikan keamanan dan kesehatan makanan, persentase populasi akses ke air minum/bersih, adanya sektor formal penyimpanan bahan makanan).

Berdasarkan lima indikator dimensi quality and safety yang telah diuraikan di atas, secara garis besar dapat dideskripsikan bahwa quality and safety pangan di Kabupaten Sukabumi dalam kategori kurang baik baik. Hal ini terlihat dari skor PPH Kabupaten Sukabumi yang baru tercapai pada angka 78,4\%, Artinya adalah proporsi keseimbangan pangan untuk memenuhi kebutuhan gizi dinilai masih kurang dari beberapa standar ideal. Perbandingan kondisi pangan berdasarkan indikator quality and safety atau kualitas dan keamanan pangan, secara umum Kabupaten Sukabumi berada satu tingkat dibawah nasional. Artinya quality and safety pangan Kabupaten Sukabumi lebih rendah daripada nasional, sehingga hal tersebut perlu diperhatikan dan ditingkatkan lagi. 
Selanjutnya secara lebih mendalam, pemetaan ketahanan dan kerentanan pangan Kabupaten Sukabumi akan diproyeksikan berdasarkan Peta Food Security and Vulnerability Atlas (FSVA) tahun 2017 dengan menggunakan tujuh indikator, yaitu: jumlah warung atau toko kelontong; persentase penduduk hidup di bawah garis kemiskinan; akses penghubung yang memadai; persentase rumah tangga tanpa akses listrik; jumlah sarana/fasilitas kesehatan; jumlah penderita gizi buruk; dan jumlah kematian balita dan ibu melahirkan. Peta dibuat dengan menggunakan pola warna yang seragam yaitu gradasi warna merah dan hijau. Gradasi warna merah menunjukkan variasi tingkat kerawanan pangan dan gradasi warna hijau menggambarkan kondisi yang lebih baik. Pada kedua kelompok warna tersebut, warna yang semakin tua menunjukkan tingkat yang lebih tinggi dalam hal ketahanan atau kerawanan pangan. Klasifikasi data pada peta untuk indikator individu menggunakan range $30 \%$ batas atas dan batas bawah, dapat dilihat pada gambar 1.

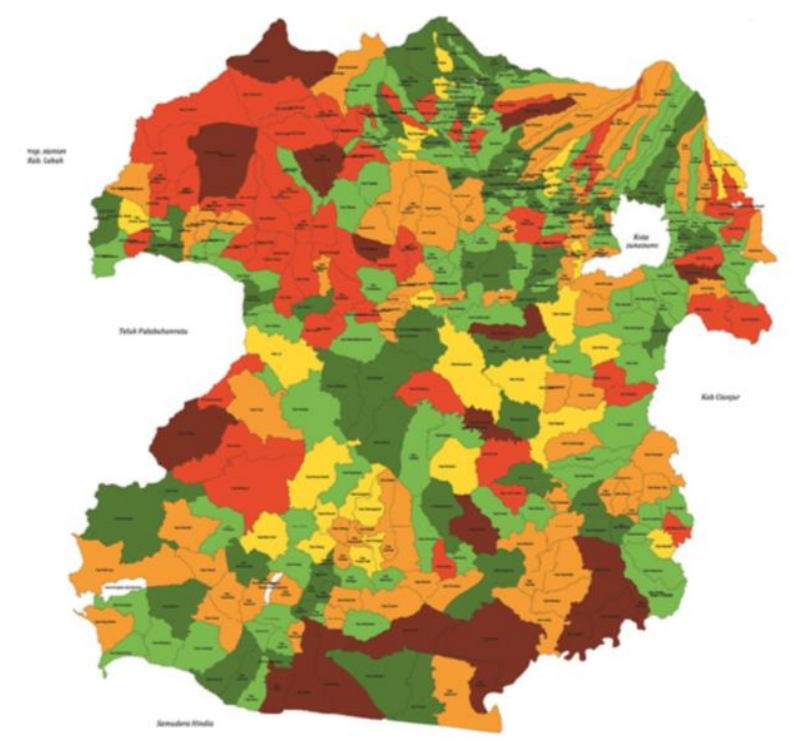

Gambar 1.

Peta Food Security and Vulnerability Atlas Kabupaten Sukabumi Tahun 2017 Sumber: Dinas Ketahanan Pangan Kabupaten Sukabumi, 2017

Berdasarkan peta komposit di atas dapat dilihat tingkat ketahanan dan kerentanan pangan Kabupaten Sukabumi yang terdiri dari 47 kecamatan, 381 desa dan 5 kelurahan. Berdasarkan gradasi warna, peta dibagi menjadi 6 prioritas penanganan. Prioritas 1 merupakan prioritas utama yang menggambarkan tingkat kerentanan yang paling tinggi, sedangkan prioritas 6 merupakan prioritas yang relatif lebih tahan pangan. Wilayah (kecamatan) prioritas 1 memiliki tingkat resiko kerawanan pangan yang lebih besar dibandingkan wilayah (kecamatan) lainnya sehingga memerlukan perhatian 
segera. Meskipun demikian, wilayah (kecamatan) yang berada pada prioritas 1 tidak berarti semua penduduknya (desa) berada dalam kondisi rawan pangan, juga sebaliknya wilayah (kecamatan) pada prioritas 6 tidak berarti semua penduduknya (desa) tahan pangan. Keterangan lebih lanjut mengenai pembagian prioritas dapat dilihat pada tabel 2.

Berikutnya melakukan perbandingan peta ketahanan dan kerentanan pangan Kabupaten Sukabumi dengan nasional. Peta FSVA nasional adalah hasil analisis tahun 2018, merupakan pemutakhiran data dari FSVA tahun 2009 dan 2015 dengan memperluas cakupan analisis yang mana memasukkan beberapa pemekaran kabupaten baru yang terbentuk dalam beberapa tahun terakhir. Pada FSVA 2018 ini jumlah kabupaten yang dianalisis sebanyak 416 kabupaten, selain itu juga dilakukan analisis pada wilayah perkotaan yang pada FSVA sebelumnya tidak dianalisis, yaitu sebanyak 98 kota. Total cakupan kabupaten dan kota yang dianalisis pada FSVA 2018 sebanyak 512 kabupaten/kota.

\section{Tabel 2. Indeks Ketahanan Pangan Komposit}

\begin{tabular}{lllcc}
\hline No & \multicolumn{1}{c}{$\begin{array}{c}\text { Prioritas } \\
\text { Penanganan }\end{array}$} & \multicolumn{1}{c}{ Kriteria } & $\begin{array}{c}\text { Jumlah } \\
\text { Desa }\end{array}$ & $\begin{array}{c}\text { Persentase } \\
\text { Wilayah (\%) }\end{array}$ \\
\hline 1 & Prioritas 1 & Sangat rentan pangan & 21 & 5,44 \\
2 & Prioritas 2 & Rentan pangan & 60 & 15,54 \\
3 & Prioritas 3 & Cukup rentan pangan & 87 & 22,54 \\
4 & Prioritas 4 & Cukup tahan pangan & 28 & 7,25 \\
5 & Prioritas 5 & Tahan pangan & 114 & 29,53 \\
6 & Prioritas 6 & Sangat tahan pangan & 76 & 19,69 \\
\hline Jumlah & & & 386 & 100,00 \\
\hline
\end{tabular}

Sumber: telah diolah kembali dari DKP Kab. Sukabumi, 2017

Perbedaan pengukuran FSVA skala nasional dengan kabupaten terletak pada penetapan indikatornya. Jika FSVA pada kabupaten hanya menggunakan 7 indikator, maka FSVA nasional dengan cakupan lebih luas dan kompleks diukur menggunakan 9 indikator, yaitu: rasio konsumsi normatif per kapita terhadap ketersediaan bersih beras + jagung + ubi jalar + ubi kayu; persentase penduduk yang hidup di bawah garis kemiskinan; persentase rumah tangga dengan proporsi pengeluaran untuk pangan lebih dari $65 \%$ terhadap total pengeluaran; persentase rumah tangga tanpa akses listrik; rata-rata lama sekolah perempuan diatas 15 tahun; persentase rumah tangga tanpa akses ke air bersih; rasio jumlah penduduk per tenaga kesehatan terhadap tingkat kepadatan penduduk; persentase balita dengan tinggi badan di bawah standar (stunting); dan angka harapan hidup pada saat lahir. Hasil analisis indikator dan komposit divisualisasikan dalam bentuk peta seperti pada gambar 2.

Berdasarkan analisis peta komposit ketahanan pangan di atas, dikelompokkan dalam enam kelompok prioritas sebagai berikut: Prioritas 1 $(4 \%)$, Prioritas $2(3,5 \%)$, Prioritas $3(5,5 \%)$, Prioritas $4(10 \%)$, Prioritas $5(33 \%)$ 
dan Prioritas 6 (43,5\%). Selanjutnya gambaran perbandingan ketahanan dan kerentanan pangan Kabupaten Sukabumi dan nasional, untuk lebih memudahkan dapat dilihat pada grafik 1 .

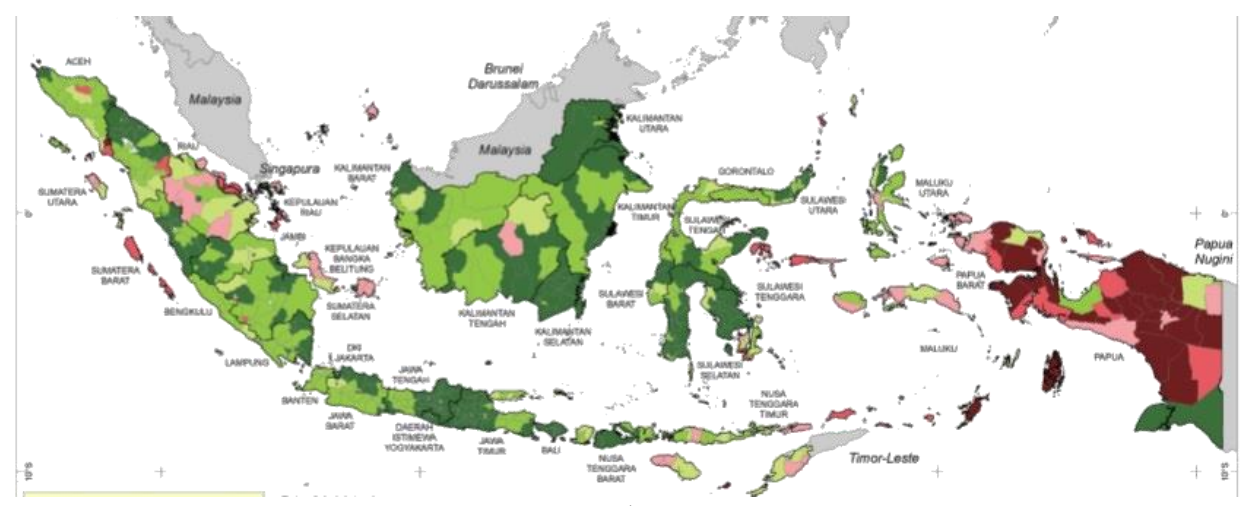

Gambar 2.

Peta Ketahanan dan Kerentanan Pangan Indonesia Tahun 2018

Sumber: Badan Ketahanan Pangan, 2018a

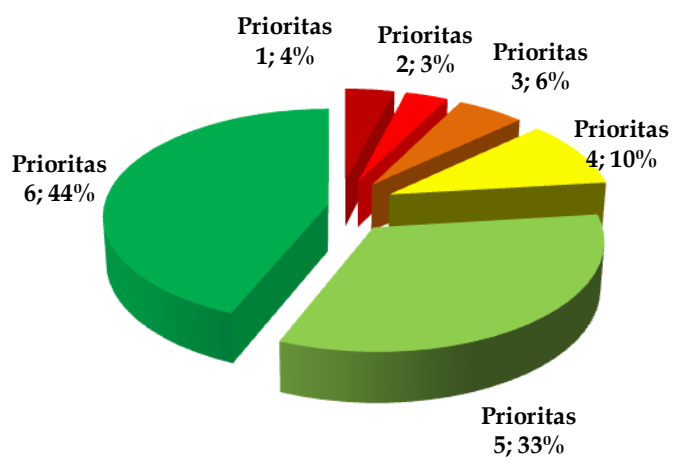

INDONESIA

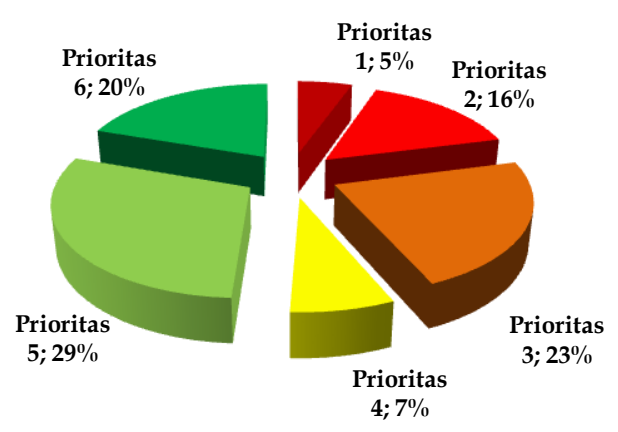

KABUPATEN SUKABUMI

\section{Grafik 1.}

\section{Perbandingan FSVA Nasional Tahun 2018 dan} FSVA Kabupaten Sukabumi Tahun 2017

Merujuk pada grafik 1, dapat dilihat secara global bahwa peta ketahanan dan kerentanan pangan nasional lebih tahan pangan dibandingkan dengan Kabupaten Sukabumi. Hal ini dapat diamati pada prioritas 1-3 (rentan pangan), wilayah Indonesia yang sangat rentan pangan hanya $4 \%$, rentan pangan $3 \%$, dan cukup rentan pangan 6\%. Angka tersebut jauh lebih kecil dibandingkan Kabupaten Sukabumi yang tercatat sangat rentan pangan 5\%, rentan pangan $16 \%$, dan cukup rentan pangan $23 \%$. Artinya kerentanan pangan diwilayah Kabupaten Sukabumi masih lebih rawan dibandingkan dengan kerentanan pangan nasional Indonesia. Sebaliknya melihat prioritas 4-6 (tahan pangan) 
wilayah Indonesia sesuai data bahwa angka cukup tahan pangan $10 \%$, tahan pangan 33\%, dan sangat tahan pangan $44 \%$. Wilayah Kabupaten Sukabumi menunjukkan angka cukup tahan pangan $7 \%$, tahan pangan $29 \%$, dan sangat tahan pangan $20 \%$. Artinya bahwa daya tahan pangan Indonesia secara keseluruhan masih lebih tahan pangan dibandingkan dengan daya tahan pangan Kabupaten Sukabumi. Kesimpulannya, secara garis besar dapat dikatakan bahwa daya tahan pangan Indonesia masih lebih baik dibandingkan dengan daya tahan pangan Kabupaten Sukabumi.

\section{Pembahasan}

Analisis faktor strategi SWOT digunakan untuk menganalisis berbagai faktor internal (strength dan weakness) dan juga faktor eksternal (opportunity dan threat) yang mempengaruhi ketahanan pangan di Kabupaten Sukabumi dalam meminimalisasi fenomena kejadian stunting diwilayah tersebut. Identifikasi faktor-faktor internal dikelompokkan menjadi faktor kekuatan (strength) dan faktor kelemahan (weakness). Faktor kekuatan (strength) terdiri dari: tersedianya komoditas tanaman pangan dan ternak; lembaga struktural ketahanan pangan dan gizi; dukungan infrastruktur; komitmen kepala daerah; dan dukungan bidang teknis dan koordinatif. Faktor kelemahan (weakness) terdiri dari: kualitas konsumsi pangan rendah; masih besarnya jumlah desa rawan pangan; daya beli masyarakat rendah; dan pola konsumsi masyarakat yang belum beragam/ proses diversifikasi berjalan lamban.

Identifikasi faktor-faktor eksternal dikelompokkan menjadi faktor peluang (opportunity) dan faktor ancaman (threat). Faktor peluang (opportunity) terdiri dari: jumlah penduduk besar; banyaknya industri pengolahan bahan pangan; dan perkembangan teknologi produksi pangan. Faktor ancaman (threat) terdiri dari: perubahan iklim (climate change) tidak menentu; konversi lahan pertanian menjadi lahan non pertanian; terbukanya industri non pertanian; dan laju pertumbuhan konsumsi rumah tangga.

Analisis formulasi strategi ketahanan pangan kabupaten sukabumi dalam meminimalisasi stunting berdasarkan External Factor Evaluation (EFE), setelah proses identifikasi dan evaluasi berbagai faktor eksternal yang berpengaruh terhadap ketahanan pangan, berikutnya dilakukan pembobotan dari masingmasing unsur tersebut. Besaran nilai/rate antara 1-4 dengan skala: 4=Sangat Baik; 3=Baik; 2=Cukup; 1=Tidak Baik; dan nilai negatif berlaku sebaliknya. Penentuan besaran nilai bobot dan rate merupakan hasil analisis Dinas Ketahanan Pangan berdasarkan skala prioritas dan urgensi yang terjadi dilapangan. Selanjutnya bobot tiap unsur dikalikan rate untuk mendapatkan skor pembobotan dan total nilai faktor eksternal. Hasil pengolahan data tersebut dapat dilihat pada tabel 3. 
Tabel 3. EFE (External Factor Evaluation) Ketahanan Pangan Kabupaten Sukabumi

\begin{tabular}{|c|c|c|c|c|}
\hline No & Faktor Eksternal & Bobot & Rate & Skor \\
\hline & \multicolumn{4}{|l|}{ Peluang } \\
\hline 1 & Jumlah penduduk besar & 0.40 & 4 & 1.6 \\
\hline 2 & $\begin{array}{l}\text { Banyaknya industri pengolahan bahan } \\
\text { pangan }\end{array}$ & 0.35 & 3 & 1.05 \\
\hline \multirow[t]{2}{*}{3} & Perkembangan teknologi produksi pangan & 0.25 & 2 & 0.5 \\
\hline & \multicolumn{4}{|l|}{ Ancaman } \\
\hline 1 & $\begin{array}{l}\text { Perubahan Iklim (climate change) tidak } \\
\text { menentu }\end{array}$ & 0.3 & -4 & -1.2 \\
\hline 2 & $\begin{array}{l}\text { Konversi lahan pertanian menjadi lahan } \\
\text { nonpertanian }\end{array}$ & 0.2 & -3 & -0.6 \\
\hline 3 & Terbukanya industri nonpertanian & 0.2 & -4 & -0.8 \\
\hline 4 & Laju pertumbuhan konsumsi rumah tangga & 0.3 & -4 & -1.2 \\
\hline & Total & 1.0 & & -0.65 \\
\hline
\end{tabular}

Selanjutnya hasil pengolahan data Internal Factor Evaluation (IFE) dapat dilihat pada tabel di bawah ini:

Tabel 4. IFE (Internal Factor Evaluation) Ketahanan Pangan Kabupaten Sukabumi

\begin{tabular}{|c|c|c|c|c|}
\hline No & Faktor Internal & Bobot & Rate & Skor \\
\hline & \multicolumn{4}{|l|}{ Kekuatan } \\
\hline 1 & $\begin{array}{l}\text { Tersedianya komoditas tanaman pangan } \\
\text { dan ternak }\end{array}$ & 0.2 & 4 & 0.8 \\
\hline 2 & $\begin{array}{l}\text { Lembaga struktural ketahanan pangan dan } \\
\text { gizi }\end{array}$ & 0.08 & 2 & 0.16 \\
\hline 3 & Dukungan infrastruktur & 0.15 & 2 & 0.3 \\
\hline 4 & Komitmen kepala daerah & 0.15 & 2 & 0.3 \\
\hline \multirow[t]{2}{*}{5} & Dukungan bidang teknis dan koordinatif & 0.1 & 3 & 0.3 \\
\hline & \multicolumn{4}{|l|}{ Kelemahan } \\
\hline 1 & Kualitas konsumsi pangan rendah & 0.1 & -3 & -0.3 \\
\hline 2 & $\begin{array}{l}\text { Masih Besarnya Jumlah Desa Rawan } \\
\text { Pangan }\end{array}$ & 0.08 & -3 & -0.24 \\
\hline 3 & Daya beli masyarakat rendah & 0.09 & -3 & -0.27 \\
\hline \multirow[t]{2}{*}{4} & $\begin{array}{l}\text { Pola konsumsi masyarakat yang belum } \\
\text { beragam/proses diversifikasi berjalan } \\
\text { lamban }\end{array}$ & 0.05 & -2 & 0.1 \\
\hline & Total & 1.0 & & 0.95 \\
\hline
\end{tabular}

Berdasarkan hasil perhitungan dari matrik EFE dan IFE kemudian dipakai untuk menentukan grand strategy untuk meningkatan ketahanan pangan di Kabupaten Sukabumi dalam meminimalisasi stunting. Analisis pada 
matrik EFE menghasilkan total skor faktor eksternal sebesar -0.65. Tanda negatif pada skor faktor eksternal berarti bahwa ancaman yang ada di Kabupaten Sukabumi lebih dominan daripada peluang yang ada. Sedangkan Analisis pada matrik IFE menghasilkan total skor faktor internal sebesar 0.95 yang berarti bahwa Kabupaten Sukabumi mempunyai kekuatan yang cukup dominan dibandingkan kelemahan yang ada. Hasil analisis menunjukkan bahwa Grand Strategy berada pada kuadran II (S-T) dengan pernyataan Strategi Diversifikasi, yaitu pernyataan yang menghendaki pencapaian performa ketahanan pangan Kabupaten Sukabumi dengan dukungan kekuatan internal yang besar, meskipun dalam pencapaian performa tersebut ketahanan pangan Kabupaten Sukabumi menghadapi beberapa ancaman eksternal. Strategi S-T untuk lebih jelasnya dapat dilihat pada grafik di bawah ini:

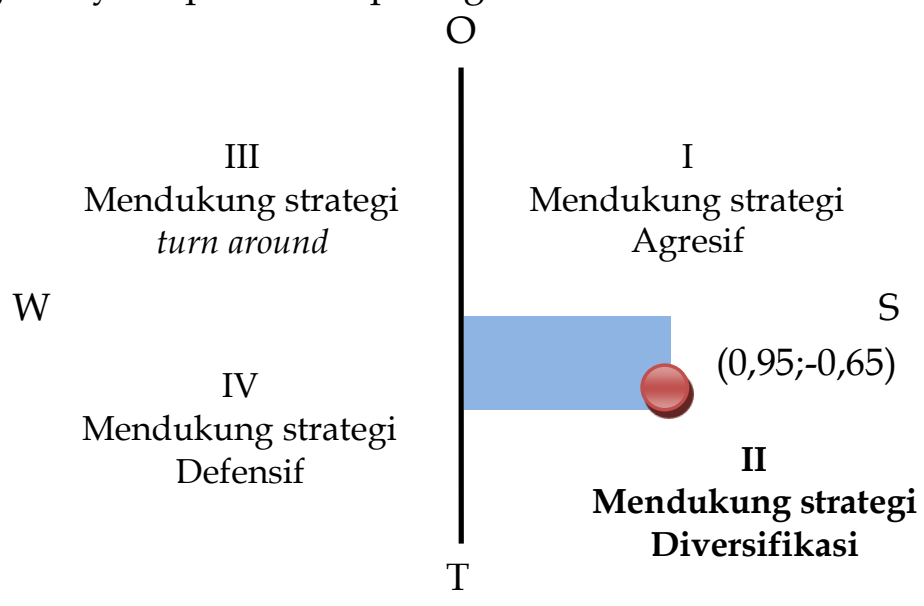

Grafik 2.

\section{Grand Strategy SWOT}

Berdasarkan hasil analisis faktor internal dan faktor eksternal, alternatif strategi dapat disusun mengikuti tabel EFE dan IFE di atas. Penjabaran pada tabel EFE yaitu peluang dan ancaman, serta pernjabaran pada tabel IFE yaitu kekuatan dan kelemahan, dimasukkan ke dalam matriks SWOT untuk menentukan alternatif strategi yang memungkinkan dapat digunakan. Strategi yang dapat disusun yaitu strategi SO, ST, WO, dan WT, secara lebih terperinci dapat dilihat pada tabel 5 .

Kabupaten Sukabumi dalam rangka meningkatkan ketahanan pangan sekaligus untuk meminimalisasi stunting sesuai matriks SWOT yang telah dijabarkan di atas, maka strategi yang digunakan adalah Strategi Strength Threats (ST) melalui: diversifikasi pangan; optimalisasi ketersediaan pangan dan ternak; penyediaan lapangan kerja pada industri pertanian; dan membatasi konversi lahan pertanian. 


\section{Tabel 5. Matriks SWOT}

\begin{tabular}{|c|c|c|}
\hline Faktor Eksternal & $\begin{array}{l}\text { STRENGTH (S) } \\
\text { 1. Tersedianya komoditas } \\
\text { tanaman pangan dan ternak } \\
\text { 2. Lembaga struktural } \\
\text { ketahanan pangan } \\
\text { 3. Dukungan infrastruktur } \\
\text { 4. Komitmen kepala daerah } \\
\text { 5. Dukungan bidang teknis } \\
\text { dan koordinatif }\end{array}$ & $\begin{array}{l}\text { WEAKNESSES }(\mathbf{W}) \\
\text { 1. Kualitas konsumsi pangan } \\
\text { rendah } \\
\text { 2. Masih Besarnya Jumlah } \\
\text { Desa Rawan Pangan } \\
\text { 3. Daya beli masyarakat } \\
\text { rendah } \\
\text { 4. Pola konsumsi masyarakat } \\
\text { yang belum beragam/ } \\
\text { proses diversifikasi berjalan } \\
\text { lamban } \\
\end{array}$ \\
\hline $\begin{array}{l}\text { OPPORTUNITIES (O) } \\
\text { 1. Jumlah penduduk besar } \\
\text { 2. Banyaknya industri } \\
\text { pengolahan bahan pangan } \\
\text { 3. Perkembangan teknologi } \\
\text { produksi pangan }\end{array}$ & $\begin{array}{l}\text { STRATEGI SO } \\
\text { 1. Optimalisasi komoditas } \\
\text { pangan }(\mathrm{S} 1: \mathrm{O} 2) \\
\text { 2. Pengembangan produk } \\
\text { pangan dan ternak }(\mathrm{S} 1, \mathrm{~S} 2: \mathrm{O} 2) \\
\text { 3. Penerapan tehnologi pangan } \\
\text { untuk menambah nilai jual } \\
\text { (S3:O2,O3) } \\
\text { 4. Promosi produk pangan lokal } \\
(\mathrm{S} 4, \mathrm{~S} 5: \mathrm{O} 2, \mathrm{O} 3)\end{array}$ & $\begin{array}{l}\text { STRATEGI WO } \\
\text { 1. Meningkatkan kualitas } \\
\text { konsumsi pangan (W1:O1) } \\
\text { 2. Optimalisasi industri } \\
\text { pangan (W2,W3:O2) } \\
\text { 3. Promosi diversifikasi } \\
\text { pangan (W4:O3) }\end{array}$ \\
\hline $\begin{array}{l}\text { THREATS }(\mathrm{T}) \\
\text { 1. Perubahan Iklim (climate } \\
\text { change) tidak menentu } \\
\text { 2. Konversi lahan pertanian } \\
\text { menjadi lahan non } \\
\text { pertanian } \\
\text { 3. Terbukanya industri non } \\
\text { pertanian } \\
\text { 4. Laju pertumbuhan } \\
\text { konsumsi rumah tangga }\end{array}$ & $\begin{array}{l}\text { STRATEGI ST } \\
\text { 1. Diversifikasi pangan (S1:T1) } \\
\text { 2. Optimalisasi ketersediaan } \\
\text { pangan dan ternak (S1,S2:T4) } \\
\text { 3. Penyediaan lapangan kerja } \\
\text { pada industri pertanian } \\
\text { (S3:T3) } \\
\text { 4. Membatasi konversi lahan } \\
\text { pertanian (S4,S5:T2) }\end{array}$ & $\begin{array}{l}\text { STRATEGI WT } \\
\text { 1. Meningkatkan kualitas } \\
\text { ketersediaan pangan } \\
\text { (W1:T1,T2) } \\
\text { 2. Optimalisasi sumber } \\
\text { pendapatan masyarakat } \\
\text { (W2,W3:T3) } \\
\text { 3. Pembinaan dan pelatihan } \\
\text { masyarakat (W4:T4) }\end{array}$ \\
\hline
\end{tabular}

\section{SIMPULAN DAN SARAN}

\section{Simpulan}

Berdasarkan hasil analisis dan pembahasan, beberapa simpulan terkait peningkatan ketahanan pangan dan stunting di Kabupaten Sukabumi:

1. Ketahanan pangan Kabupaten Sukabumi ditinjau dari dimensi affordability, produksi pangan secara garis besar dapat dijangkau oleh seluruh lapisan masyarakat, kondisi daya beli berdasarkan persentase pengeluaran pangan di rumah tangga adalah 58,4\%. Dimensi availability, ketersediaan pangan telah memenuhi standar ideal, skor ketersediaan energi sebesar 2,398 $\mathrm{kkal} / \mathrm{kap} /$ hari (AKE ideal: 2.000) dan ketersediaan protein sebesar 88 gram/kap/hari (AKP ideal: 52). Sementara dimensi quality and safety belum memenuhi standar ideal, skor Pola Pangan Harapan berada pada angka 78,4\% (PPH ideal: 100\%). 
2. Pemetaan ketahanan pangan Kabupaten Sukabumi ditinjau berdasarkan Food Security and Vulnerability Atlas, jumlah desa rawan pangan masih cukup besar. Terdapat 168 desa rawan pangan dengan klasifikasi 21 desa kategori sangat rentan pangan, 60 desa kategori rentan pangan, dan 87 desa kategori cukup rentan pangan. Selebihnya 218 desa masuk kategori cukup dan tahan pangan. Kategori desa rawan pangan diakibatkan oleh faktor kemiskinan, rumah tangga tanpa akses listrik, terbatasnya sarana kesehatan, terbatasnya jumlah warung pangan, gizi buruk, dan akses jalan yang belum memadai.

3. Strategi peningkatan ketahanan pangan dalam meminimalisasi stunting di Kabupaten Sukabumi diperoleh melalui analisis EFE dan IFE serta matriks SWOT. Grand Strategy yang paling tepat digunakan untuk mengatasi permasalahan tersebut adalah Strategi Strength Threath dengan pernyataan Strategi Diversifikasi melalui: (1) diversifikasi pangan; (2) optimalisasi ketersediaan pangan dan ternak; (3) penyediaan lapangan kerja pada industri pertanian; dan (4) membatasi konversi lahan pertanian.

\section{Saran} berikut:

Berdasarkan penelitian, saran yang dapat disampaikan adalah sebagai

1. Pemerintah Kabupaten Sukabumi perlu melakukan kontrol atau mengeluarkan kebijakan terkait pengaturan ekspor pangan, izin konversi tanah, dan penyediaan lapangan pekerjaan di bidang pangan, agar kebutuhan pangan lokal dapat terpenuhi, lahan pertanian tidak semakin berkurang, dan menarik minat masyarakat untuk turut serta berkontribusi dalam meningkatkan ketahanan pangan.

2. Pemerintah perlu melakukan upaya koordinasi yang sinergi dan berkesinambungan antar lembaga dalam meningkatkan ketahanan pangan dan penanganan stunting. Guna meningkatan sarana dan prasarana baik dibidang pangan maupun kesehatan yang memadai. Selanjutnya percepatan program diversifikasi dan edukasi pangan kepada seluruh lapisan masyarakat agar lebih memahami pentingnya pemenuhan gizi untuk mencegah dan menangani stunting.

3. Untuk penelitan selanjutnya, dapat lebih digali bagaimana perkembangan kondisi ketahanan pangan Kabupaten Sukabumi, dan anak-anak yang menderita stunting untuk kemungkinan terbebas dari stunting yang menyebabkan gangguan kognitif, motorik, dan verbal setelah berusia lebih dari 5 tahun. 


\section{DAFTAR PUSTAKA}

BPS Jawa Barat. 2018. Analisis Indikator Logistik Pangan (Beras) Provinsi Jawa Barat 2017. Bandung: Badan Pusat Statistik Provinsi Jawa Barat.

Badan Ketahanan Pangan. 2018. Direktori Perkembangan Konsumsi Pangan. Jakarta: Badan Ketahanan Pangan Kementerian Pertanian.

Badan Ketahanan Pangan. 2018. Peta Ketahanan Dan Kerentanan Pangan -Food Security And Vulnerability Atlas 2018. Jakarta: Badan Ketahanan Pangan Kementerian Pertanian.

Dewan Ketahanan Pangan. 2015. Kebijakan Strategis Pangan Dan Gizi Tahun 2015-2019. Jakarta: Kementerian Pertanian/Dewan Ketahanan Pangan.

Dinas Ketahanan Pangan Kabupaten Sukabumi. 2017. Pemetaan Ketahanan Dan Kerentanan Pangan (Food Security And Vulnerability Atlas). Sukabumi: Dinas Ketahanan Pangan Kabupaten Sukabumi.

Dinas Ketahanan Pangan Kabupaten Sukabumi. 2018. Laporan Akhir Penyusunan Analisis Neraca Bahan Makanan Kabupaten Sukabumi Tahun 2018. Sukabumi: Dinas Ketahanan Pangan Kabupaten Sukabumi.

Hamami, M. 2019. Sukabumi klaim surplus produksi beras hingga 350 ribu ton. https://nasional.republika.co.id/berita/nasional/daerah/pnqj2o414/ nasional/daerah/19/02/21/pnac4u349-sukabumi-klaim-surplusproduksi-beras-hingga-350-ribu-ton, diakses tanggal 3 Maret 2019.

Elizabeth, R. 2011. Strategi pencapaian diversifikasi dan kemandirian pangan: Antara harapan dan kenyataan. Jurnal Iptek Tanaman Pangan, 6 (2).

Global Food Security Index. 2018. https://foodsecurityindex.eiu.com/ Country/Details\#Indonesia, diakses tanggal 22 Februari 2019.

Khudori. (2009). Neoliberalisme menumpas petani: Menyingkap kejahatan industri pangan. Yogyakarta: Resist Book.

Kementerian Kesehatan. 2012. Ketahanan Pangan Dan Perbaikan Gizi Merupakan Suatu Kesatuan. Jakarta: Pusat Komunikasi Publik Setjen Kementerian Kesehatan. Publikasi pada 19 November 2012 pukul 17:00:00.

Kementerian Kesehatan. (2017). Pendekatan program kesehatan masyarakat tahun 2018. Jakarta: Direktur Jenderal Kesehatan Masyarakat. Pemaparan pada 04 Oktober 2017.

Kementerian Kesehatan. (2018). Buku Saku Pemantauan Status Gizi Tahun 2017. Jakarta: Direktorat Gizi Masyarakat Direktorat Jenderal Kesehatan Masyarakat Kementerian Kesehatan.

Keputusan Menteri Kesehatan. (2010). Keputusan Menteri Kesehatan Nomor 1995/MENKES/SK/XII/2010 tentang Standar Antropometri Penilaian Status Gizi Anak. Jakarta: Kementerian Kesehatan. 
Ketaren, A. (2015). Modal sosial petani dalam pertanian berkelanjutan dalam mendukung ketahanan pangan daerah. Lhokseumawe, Aceh: Unimal Press.

Peraturan Pemerintah. 2015. Peraturan Pemerintah RI Nomor 17 Tahun 2015 Tentang Ketahanan Pangan dan Gizi. Jakarta: Presiden RI.

Safa'at, R. 2013. Rekonstruksi Politik Hukum Pangan: Dari Ketahanan Pangan Ke Kedaulatan Pangan. Malang: UB Press.

Susilo, E. Purwanti, P. Fattah, M. 2017. Adaptasi Manusia, Ketahanan Pangan Dan Jaminan Sosial Sumberdaya. Malang: UB Press.

The Mother and Child Health and Education Trust. 2009. Protection and Support of Healthy Maternal. Infant and Young Child. www.motherandchildnutrition.org diakses tanggal 19 Februari 2019.

TNP2K. 2017. 100 Kabupaten/Kota Prioritas untuk intervensi anak Kerdil (Stunting). Jakarta: Tim Nasional Percepatan Penanggulangan Kemiskinan (TNP2K). Volume 1.

TNP2K. 2018. Gerakan Nasional Pencegahan Stunting dan Kerjasama Kemitraan Multi Sektor. Sekretariat Wakil Presiden Republik Indonesia/Tim Nasional Percepatan Penanggulangan Kemiskinan (TNP2K). Pemaparan pada Agustus 2018.

Undang-Undang. 2012. Undang-Undang Republik Indonesia Nomor 18 Tahun 2012 Tentang Pangan. Jakarta: Presiden RI.

UNICEF. 2004. Low birthweight: country, regional, and global estimate. New York: UNICEF.

Wheelen, T.L. 2008. Concept in strategic management and business policy. New Jersey: Prentice Hall, inc. Eight edition.

WHO. 2010. Nutrition landscape information system (NLIS) country profile indicators: Interpretation guide. Geneva: World Health Organization.

Interpretation guide. Geneva: World Health Organization.

274 | Hadi Riajaya, Adis Imam Munandar; Strategi Peningkatan... 